\title{
Large-Scale Circulation Patterns Associated with Heavy Spring Rain Events over Taiwan in Strong ENSO and Non-ENSO Years
}

\author{
ZHIHONG JIANG \\ Department of Atmospheric Sciences, Nanjing Institute of Meteorology, Nanjing, China \\ George Tai-Jen Chen And Ming-Chin Wu \\ Department of Atmospheric Sciences, National Taiwan University, Taipei, Taiwan
}

(Manuscript received 9 July 2002, in final form 29 January 2003)

\begin{abstract}
Daily rainfall data at 15 stations in Taiwan and the grid dataset of the National Centers for Environmental Prediction-National Center for Atmospheric Research during the period of February-March 1951-2000 were used to reveal the characteristics of large-scale circulations associated with spring heavy rain events over Taiwan in strong ENSO and non-ENSO years. The effect of interdecadal variation on the relationship of spring rainfall and ENSO was also examined.

Results showed that the different regimes of interdecadal variation that occurred in the late 1970s exert significant effect on the relationship between ENSO and spring rainfall in Taiwan. A pronounced positive correlation with statistical significance between cold season Niño-3 SST and the following spring rainfall over western Taiwan was only found since the late 1970s. Large-scale environmental conditions associated with the heavy spring rain events in strong ENSO and non-ENSO years were found to be quite different. Intrusion of a weak midlatitude frontal system into the eastern China coastal area coupled with an anomalous anticyclone over the Philippine Sea (PSAC) in the lower troposphere were primarily responsible for the spring heavy rain events in strong ENSO years. On the other hand, the intrusion of a much more intense midlatitude frontal system into China and the coastal area was necessary to generate spring heavy rain events in non-ENSO years. This difference is also instrumental for more frequent occurrence of heavy rainfall events and more rainfall amount observed in ENSO years.
\end{abstract}

\section{Introduction}

Taiwan is an island located in the subtropical latitudes $\left(22^{\circ}-26^{\circ} \mathrm{N}\right)$ to the southeast of mainland China and experiences active east Asian monsoon with prevailing northeasterlies in winter and southwesterlies in summer (Yen and Chen 2000). During the transition of the active monsoon seasons, the late winter and early spring season (February-March, generally called spring in this study) is relatively dry particularly over southwestern Taiwan to the leeside of the high Central Mountain Range (CMR) under the prevailing northeast monsoon flow. However, the spring precipitation exhibited a significant interannual variability (Chen et al. 2003). A better understanding of this variation and its mechanism is an important meteorological issue because it is closely related to the planning of many human activities and utilization of water resources over this area in dry season.

Corresponding author address: Dr. G. T. J. Chen, Dept. of Atmospheric Sciences, National Taiwan University, Taipei, Taiwan. E-mail: george@george2.as.ntu.edu.tw
There are strong evidence for a linkage between the climate of east Asia and ENSO. For example, the east Asian winter monsoon tends to be weaker and warmer (Ropelewski and Halpert 1987; Halpert and Ropelewski 1992; Tomita and Yasumarin 1996; Zhang et al. 1996; Wang et al. 2000), the spring tends to be wetter over east Asia, and the mei-yu rainfall over China tends to be greater (Wang and Hwu 1994; Kang and Jeong 1996; Tao and Zhang 1998; Wang et al. 2000) during and after the mature phase of ENSO. Wang et al. (2000) found that the physical process responsible for this link is an anomalous low-level anticyclone located over the Philippine Sea (referred to as PSAC). The PSAC develops rapidly in the fall before the mature phase of ENSO and persists until the following summer, causing anomalously wet conditions along the east Asian polar front stretching from southern China northeastward to the east of Japan (Kuroshio extension). This relationship was manifested in the so-called Pacific-East Asian teleconnection pattern (PEA) in the surface vorticity wave pattern and the surface streamfunction anomaly field that started from the central Pacific and extended poleward and westward to east Asia. Chen et al. (2003) 
found that the mean state of the PEA pattern coupled with the intrusion of midlatitude frontal systems into the eastern China coastal area were primarily responsible for the extremely heavy rain events in Taiwan during spring in ENSO years. They also showed that extremely heavy rain events occurred much more frequently in ENSO years as compared to those occurred in non-ENSO years. Therefore, it is interesting to know why the heavy rain events occur more frequently in association with the PEA pattern. What process is responsible for this correlation? How are the differences of the large-scale circulations associated with the heavy rain events in strong ENSO and non-ENSO years?

It has been noted that there was a significant shift of the environmental conditions in the late 1970s. These included the warming in the tropical Pacific, cooling in the northwestern Pacific, and a stronger Aleutian low with a southward shifting to the south of the Pacific storm track (e.g., Nitta and Yamada 1989; Trenberth and Hurrell 1994; Nakamura et al. 1997). Chang et al. (2000a,b) suggested that this shift affected the relationship between the east Asian summer monsoon and the tropical SST. Does this interdecadal variation also affect the relationship between ENSO and the spring rainfall in Taiwan? These are some of the interesting questions related to the spring rainfall in Taiwan and they will be discussed in this paper.

\section{Data and analyses}

Daily rainfall data at 15 stations in Taiwan (Fig. 1) observed from 1951 to 2000 were used to select heavy rain events and to reveal the relationship between the rainfall over Taiwan and ENSO. The dataset used to analyze the large-scale environmental conditions is the National Centers for Environmental Prediction-National Center for Atmospheric Research (NCEP-NCAR) global atmospheric reanalysis dataset covering a 50-yr period of February and March 1951-2000. A detailed description of the data assimilation system that produced this dataset was given by Kalnay et al. (1996). The data assimilation system was based on the global forecast model that was implemented operationally at NCEP in January 1995 . The daily data at standard pressure levels at $2.5^{\circ}$ long $\times 2.5^{\circ}$ lat grids were used in this study.

Since the mean sea surface temperature anomaly (SSTA) over the central and eastern equatorial Pacific reflected the mature phase of El Niño or La Niña events in the cold season of November-March (e.g., Ropelewski and Halpert 1987; Wang et al. 2000), the SSTA of this season over Niño-3 $\left(5^{\circ} \mathrm{S}-5^{\circ} \mathrm{N}, 90^{\circ}-150^{\circ} \mathrm{W}\right)$ was used to identify the warm, cold, and normal episodes. One standard deviation of SSTA $\left(0.7^{\circ} \mathrm{C}\right)$ appeared to be a reasonable choice for differentiating warm versus cold episodes as compared to the season episodes issued by Climate Prediction Center of the National Oceanographic and Atmospheric Administration (CPC NOAA, more

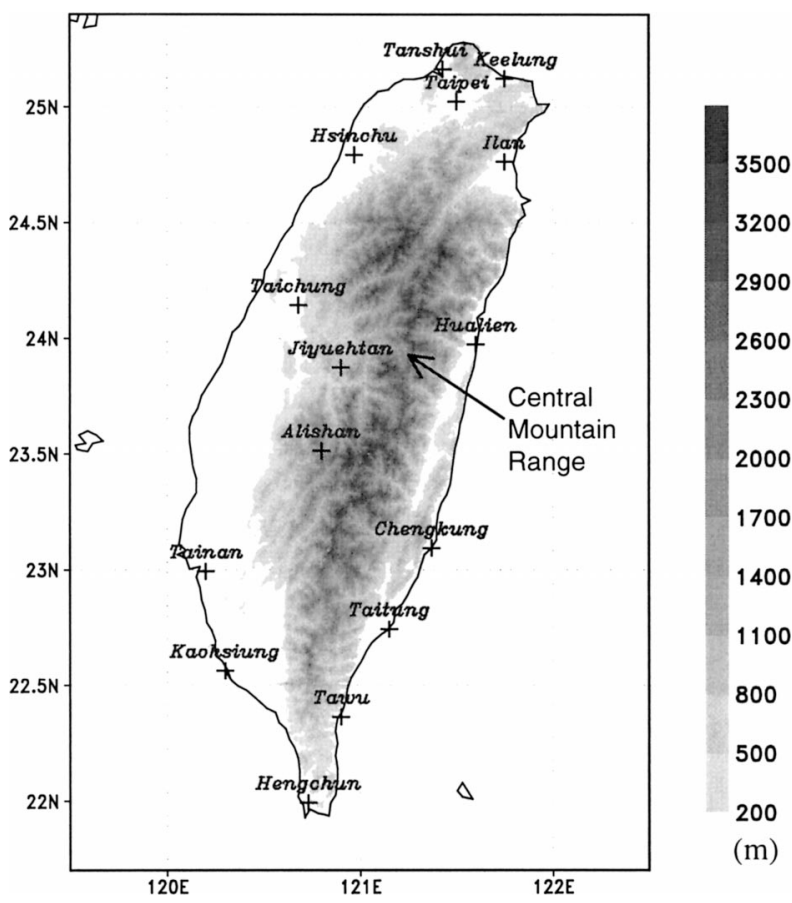

FIG. 1. Locations of the surface rainfall stations and topography (m) over Taiwan.

information available online at http://www.cpc.noaa. gov). In this study, warm and cold episodes and neutral conditions are thus defined by Niño-3 SSTA $>0.7^{\circ} \mathrm{C}$, SSTA $<-0.7^{\circ} \mathrm{C}$, and $0.7^{\circ} \mathrm{C} \geq$ SSTA $\geq-0.7^{\circ} \mathrm{C}$, respectively. It turns out that the event years of warm episodes include 1957/58, 1965/66, 1968/69, 1972/73, 1982/83, 1986/87, 1987/88, 1991/92, 1994/95, and 1997/98 during the period of 1951-2000. The event years of warm episodes are referred to ENSO years thereafter. The cold episode event years include 1950/ 51, 1954/55, 1955/56, 1970/71, 1973/74, 1975/76, 1984/85, 1988/89, 1995/96, 1998/99, and 1999/2000. The other years are classified as neutral conditions. The event years of cold and neutral conditions composed non-ENSO years.

To examine the effect of ENSO on regional rainfall in different seasons, correlation coefficients between monthly rainfall over Taiwan and Niño-3 SST from the preceding year to the concurrent year were analyzed. In order to consider the possible effects of the interdecadal changes over Pacific in the late 1970s, a wavelet transform (WT) (Morlet 1983) was performed to reveal the evolution of the relationship between Niño-3 SST and spring rainfall over Taiwan. Wavelet transform is an analysis tool well suited to study multiscale, nonstationary processes occurring over finite spatial and temporal domains. Unlike Fourier analysis, which yields an average amplitude and phase for each harmonic in a dataset, WT produces an "instantaneous" estimate for the amplitude and phase of each harmonic. Therefore, WT has wide application in diverse fields of sciences including the atmo- 
spheric and oceanic sciences (e.g., Liu and Miller 1996; Weng and Lau 1994; Lau and Weng 1995; Kumar and Foufoula-Georgiou 1993; Wang and Wang 1996; Torrence and Compo 1998). In this study, the Morlet WT illustrated in Torrence and Compo (1998) was applied to the time series of spring (February-March) rainfall and Niño-3 SST for the cold season (November-March) from 1951 to 2000 . The length of data is $50 \mathrm{yr}$, time step is $1 \mathrm{yr}$, minimum resolve scale is $2 \mathrm{yr}$. The nondimensional frequency of the wavelet function was taken to be 6 . Thus wavelet scale is almost equal to the Fourier period (Torrence and Compo 1998). Since the major interest is on the relative phase of these two time series, the minimum width in real space $(2 \mathrm{yr})$ with maximum width in spectral space $(0.5)$ was used. The parameter values chosen gave a total of nine scales ranging from 2 to 32 yr. In order to focus on the relative phase of these two time series, a plot of the real parts of Morlet wavelet coefficients with cone of influence (Fig. 3) will be presented and discussed in the next section.

The period with larger correlations was then chosen to reveal the relationship between ENSO and the heavy rain events. The large-scale atmospheric circulation was composited for each mandatory level to reveal the characteristics associated with the heavy spring rain events in strong ENSO and non-ENSO years.

\section{Relation of spring rainfall and ENSO}

\section{a. Monthly correlation between rainfall and ENSO}

To explore the question of how closely the seasonal rainfall is related to ENSO, the monthly correlation coefficients between rainfall over Taiwan and Niño-3 SST from the preceding to the concurrent year of rainfall were presented in Fig. 2a for the period of 1951-2000. For reasons to be discussed later, the correlation coefficients for the periods of 1955-77 and 1978-2000 are also presented in Figs. $2 \mathrm{~b}$ and $2 \mathrm{c}$, respectively. The most significant correlations are between the Niño-3 SST in the period from the preceding September to the following May and the rainfall in February-March in 19512000. Note that the maximum correlation between the rainfall in February-March and Niño-3 SST occurs during the mature phase of ENSO from November to March. Therefore, the most noticeable correlation period between ENSO and rainfall in Taiwan is focused on the cold season of Niño-3 SST from November to March and the following spring rainfall in February-March.

To investigate possible interdecadal variation in the spring rainfall-ENSO relationships, a Morlet WT was applied to the time series of spring (February-March) rainfall and the time series of Niño-3 SST for the cold season (November-March) from 1951 to 2000. The real parts of Morlet wavelet coefficients with cone of influence (Torrence and Compo 1998) for spring rainfall over Taiwan and cold season SST over Niño-3 are presented (Fig. 3). Note that the edge effects become important in
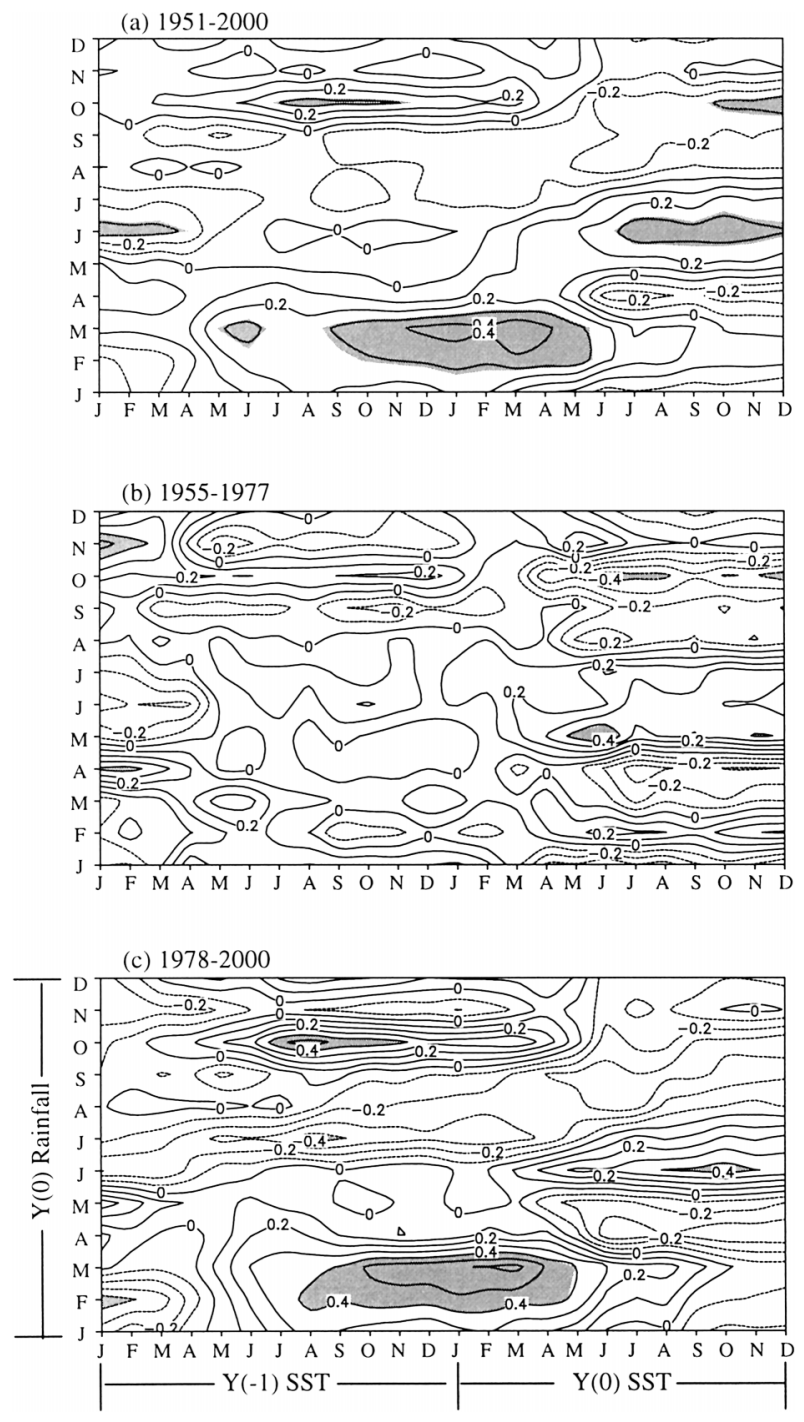

FIG. 2. (a) Correlation coefficients between monthly rainfall over Taiwan and Niño-3 SST from the preceding year $[\mathrm{Y}(-1)]$ to the concurrent year [Y(0)] in the period of (a) 1951-2000, (b) 1955-77, and (c) 1978-2000. Areas with 95\% significance level are shaded.

the regions beyond the heavy line on both sides. The spectrum of real part only for the spring rainfall and Niño3 SST in Fig. 3. is a little wavy in the short timescale as expected (Torrence and Compo 1998). Two main periods of interannual variability, that is, one around $8 \mathrm{yr}$ and another around $5 \mathrm{yr}$, appear in the time series of the spring rainfall. The former cycle was quite strong during 1951-80, while the later cycle with quasi-5-yr oscillation became particularly pronounced in the last 20 years. A noticeable feature is that the quasi-5-yr oscillation also appeared to be more pronounced for Niño-3 SST after the mid-1970s. In other words, the variations of phase and amplitude for spring rainfall and Niño-3 SST in cold season are similar since the late 1970s. The cone of influence indicates that the quasi-5-yr oscillation exhibited a pronounced correlation in the period from late 1970 


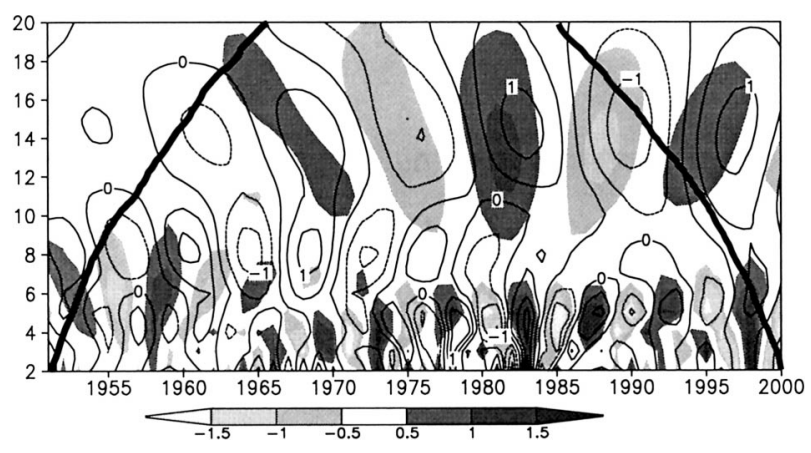

FIG. 3. The real part of Morlet wavelet coefficients for spring rainfall (Feb-Mar) over Taiwan (contours) and cold season (NovMar) SST over Niño-3 ( $\left.5^{\circ} \mathrm{S}-5^{\circ} \mathrm{N}, 90^{\circ}-150^{\circ} \mathrm{W}\right)$ (shaded) in $1951-2000$ ( $x$ axis). Heavy solid line denotes the "cone of influence". $Y$ axis is period (year).

through mid-1990. In addition, decadal variability with 13-15-yr period also exists in both series after the mid1970s. This noticeable interdecadal change also occurred for different variables over the Pacific ocean in the late 1970s (e.g., Nitta and Yamada 1989; Trenberth and Hurrell 1994; Nakamura et al. 1997; Wang 1995). Thus, we divided the dataset into two periods, 1955-77 and 19782000, similar to that used by Weng et al. (1999) and Chang et al. (2000a,b). The monthly correlation coefficients between rainfall over Taiwan and Niño-3 SST from the preceding year to the concurrent year for these two periods are presented in Figs. $2 \mathrm{~b}$ and $2 \mathrm{c}$, respectively. It is clear that the correlations between the spring rainfall and Niño-3 SST from the preceding August to the following April were quite different in these two periods. In first period of 1955-77, the overall correlation coefficients were close to zero, while during the second period of 1978-2000 they exhibited high positive correlations. This is consistent with the WT analyses (Fig. 3), that is, the pronounced positive correlation with statistical significance between cold season SST and following spring rainfall only exists for the last 20 years in the analyzed period.

The spatial distribution of correlation coefficients between the spring rainfall and the cold season SST in 1951-2000 is presented in Fig. 4a. Positive correlation existed over all the stations with a mean correlation coefficient of 0.36 for all stations. The average correlation coefficients over the area to the west of the CMR were 0.50 , which is statistically significant at $99 \%$ level (i.e., $\geq 0.35$ ). Figures $4 \mathrm{~b}$ and $4 \mathrm{c}$ display the spatial distribution of correlation for the periods of 1955-77 and 1978-2000, respectively. In the first period, no significant correlation coefficient was observed at any station. However, very high positive correlations existed at all the stations with a mean correlation coefficient of 0.51 in the second period. It is interesting to note that the correlation coefficients were greater than 0.6 at most stations over western Taiwan in 1978-2000 with 99\% significance level (i.e., $\geq 0.50$ ), much higher than that in 1951-2000. Apparently, only the spring rainfall in 1978-2000 over western Taiwan was highly correlated with SST over the Niño-3 region. This is also true for the March rainfall over the southeastern coastal areas of mainland China as presented in Fig. 5.

\section{b. Spring heavy rain events and SST}

In view of the high correlation between spring rainfall over western Taiwan and Niño-3 SST in 1978-2000, it is interesting to know specifically how the heavy rain event over the western Taiwan was related to the SST over Niño3. This is presented in Fig. 6 for the top 50 cases and top 25 cases of daily rainfall events. The daily rainfall here is referred to the 1-2-1 running mean daily rainfall computed from the eight stations over western Taiwan as illustrated in Fig. 4c. Time series of daily rainfall in February-March of 1978-2000 are presented in Fig. 7. It is clear that heavy rain events over western Taiwan occurred much more frequently in the ENSO years at $95 \%$ significance level as compared to those occurred in non-ENSO years. About three events would be expected to occur annually in ENSO years but less than two events would be expected to occur in non-ENSO years for the top 50 daily rainfall events. About two events for ENSO years but less than one event in non-ENSO years would be expected to occur annually for the top 25 daily rainfall events. Interesting questions arise regarding the main differences for the large-scale circulations associated with the heavy rain events in ENSO and non-ENSO years. Six top daily rainfall events occurred in ENSO and non-ENSO years were selected (Table 1, Fig. 7) to study the characteristics of the accompanied large-scale environmental conditions. The cases selected had daily rainfall anomalies greater than 3.5 standard deviations and can be considered as extremely heavy rain events in spring over Taiwan. The averaged date of the six cases was 7 March in ENSO years and 8 March in non-ENSO years. Thus, the heavy rain events in ENSO and non-ENSO years can be considered to occur under the similar climate conditions. The general features of the mean circulations for the top 25 rain events in ENSO years resemble to those of composite for the six extremely heavy rain events, although with a relatively weak intensity. Similar situations existed in non-ENSO years as well. Since the synoptic patterns at different levels for each individual case are quite similar to each other and resemble the composite maps, large-scale circulations revealed by the composite will be discussed in the next section. Notice that five out of six extremely heavy rain events selected in ENSO years occurred in the strong ENSO years of 1983 and 1998. Thus, the characteristics of the associated largescale circulations revealed by composite analyses should reflect more influence of strong ENSO events.

\section{Conditions associated with heavy rain events \\ a. Large-scale circulations}

Note that all of the six extremely spring heavy rain events in both strong ENSO and non-ENSO years oc- 
(a) $1951-2000$

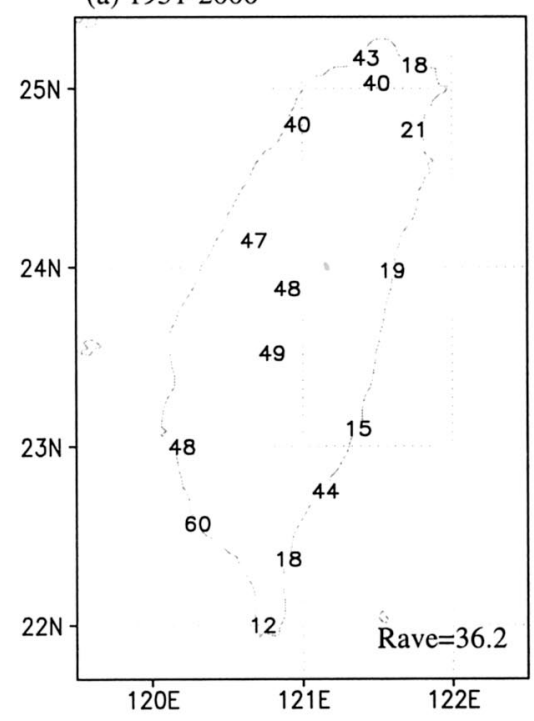

(c) $1978-2000$

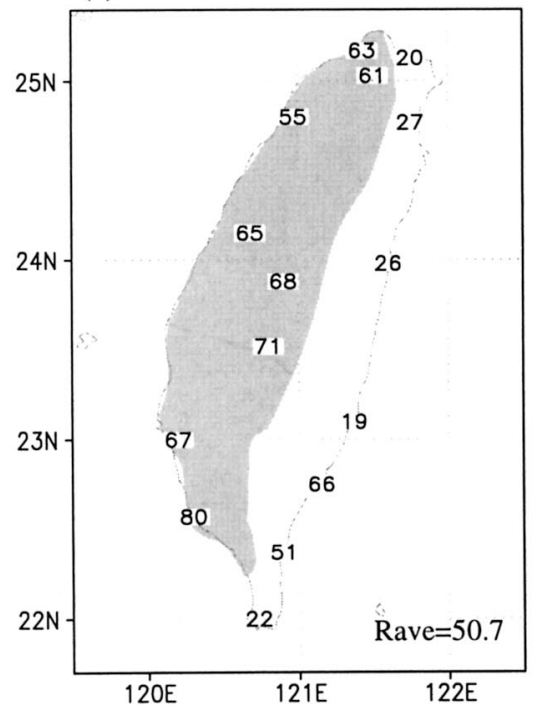

curred in February and March and the averaged event dates were very close to each other (Table 1). Therefore, the long-term mean in February-March will be considered as the climatological mean state for spring season. All the meterological variables were averaged with respect to the event day to obtain the composite fields. The anomaly fields were then obtained by subtracting the climatological mean state from the composite fields. Synoptic situations at different mandatory levels will be compared for both cases in using the composite and the anomaly fields. Besides, the differences of the spring long-term mean situations between strong ENSO and non-ENSO years will also be presented and discussed.

Figures 8 and 9 present the geopotential height and wind fields at $1000 \mathrm{hPa}$. The climatological mean state

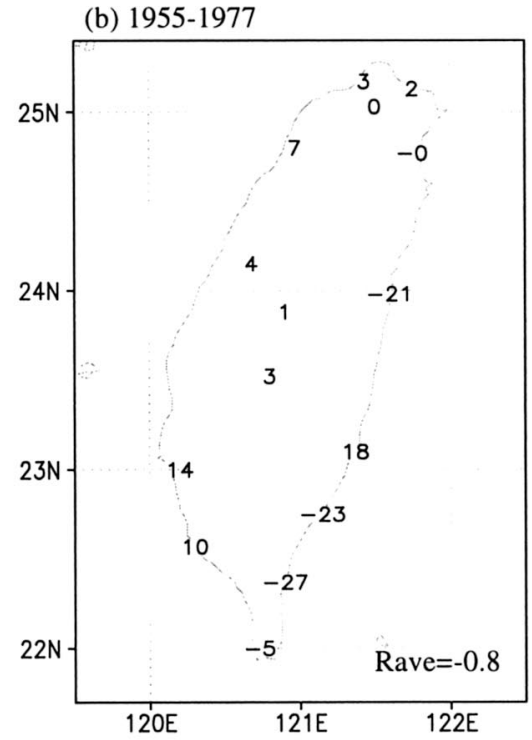

FIG. 4. Correlation coefficients between SST over Niño-3 in the preceding cold season (Nov-Mar) and the following spring (FebMar) rainfall over Taiwan during (a) 1951-2000, (b) 1955-77, and (c) 1978-2000. Numbers indicate correlation coefficients in 0.01 unit and Rave is the averaged value. Western Taiwan as represented by eight stations is shaded.

indicated that the western Pacific trough extended from the east of Japan southwestward to the east of Taiwan (Fig. 8a). Northeast monsoon flows prevailed over the South China Sea, the Philippine Sea, and the western Pacific. The difference in the long-term mean state in ENSO and non-ENSO years (Fig. 8b) showed a region of strong anomalous southwesterlies over the South China Sea and the western Pacific, indicating the weakening of northeast monsoonal flows in ENSO years. Also, a weak anomalous anticyclone associated with positive geopotential anomaly exists over the western Pacific and the Philippine Sea. This is consistent with the PEA teleconnection pattern during mature phase of ENSO as proposed by Wang et al. (2000). During the heavy rain events for both cases, a frontal trough was extended 
(a) $1951-2000$

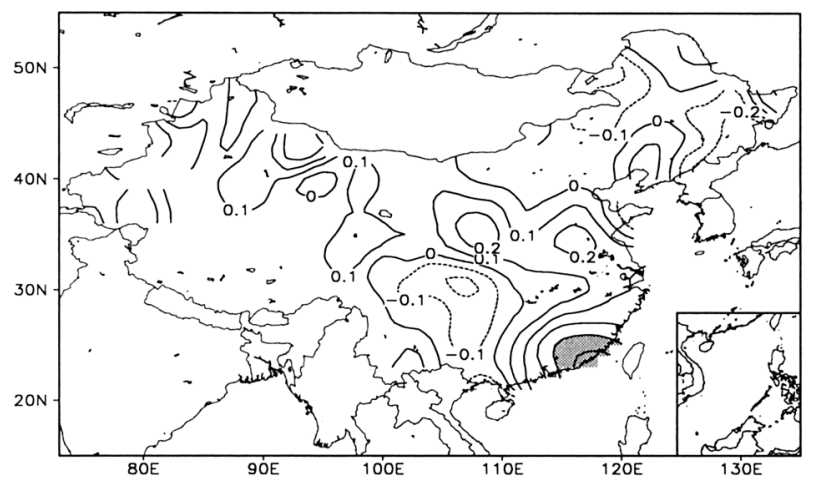

(b) 1951-1977

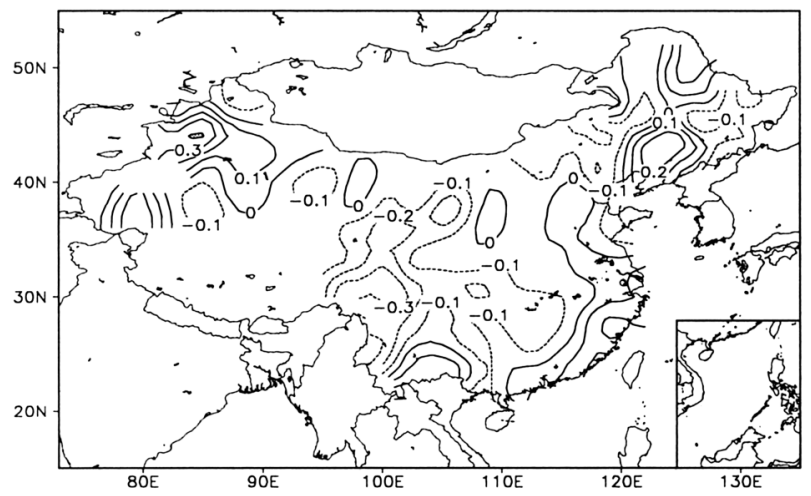

(c) $1978-2000$

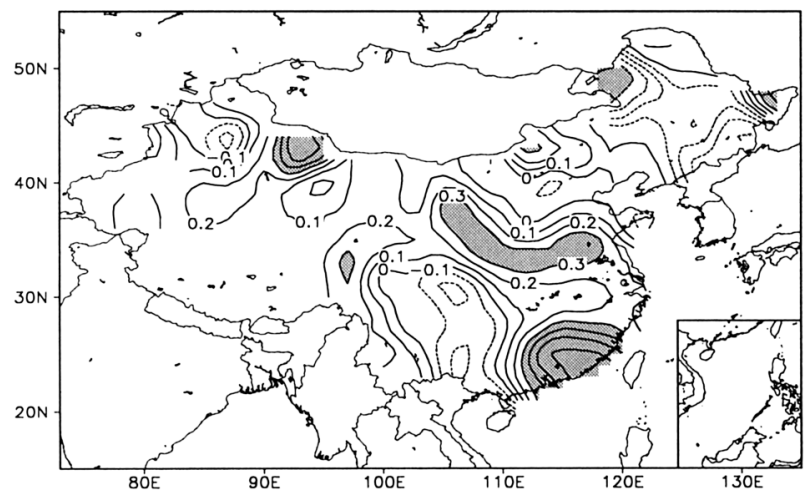

FIG. 5. Correlation coefficients between SST over Niño-3 in the preceding cold season (Nov-Mar) and the following Mar rainfall in mainland China during (a) 1951-2000, (b) 1955-77, and (c) 19782000. Areas of correlation coefficients $\geqq 0.3$ are shaded.

from the center of an extratropical cyclone to the northeast of Japan southwestward passing through the Bashi Channel to the northern South China Sea (Figs. 9a and 9b). The strong anomalous southwesterly flows were observed to the southeast of the frontal trough although associated with different trough intensities. The strong southwesterly flow was an important ingredient during the extremely heavy rain event for supplying the moisture from the tropical area. During the heavy rain events

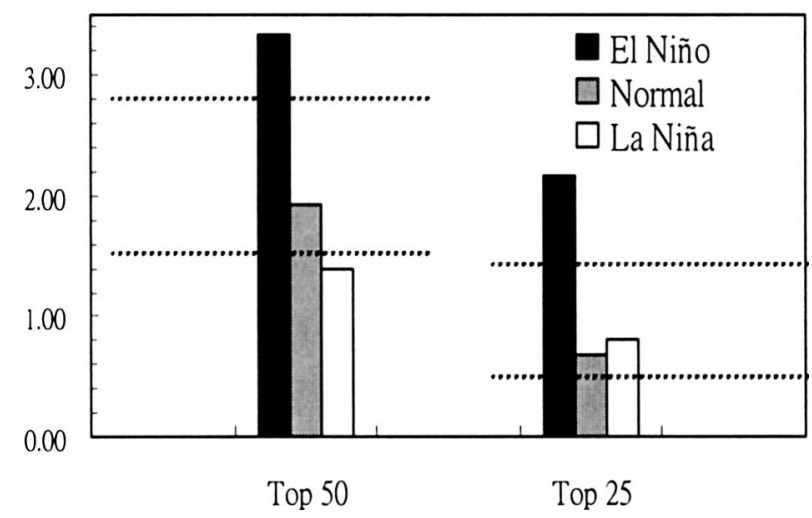

FIG. 6. Annual expectation of number of event occurrence for the top 50 cases and top 25 cases of daily rainfall events in western Taiwan during El Niño, La Niña, and normal years in 1978-2000. Dashed lines indicate $95 \%$ significance level.

in strong ENSO years (Fig. 9a), stronger anomalous anticyclonic flows with larger positive geopotential heights anomalies than those in the long-term difference of seasonal mean between ENSO and non-ENSO years (Fig. 8b) were observed over the western Pacific and the Philippine Sea. On the other hand, negative geopotential height anomalies were observed over the same area during the events in non-ENSO years (Fig. 9b). A stronger frontal trough, as indicated by the large negative geopotential height anomalies along the trough, was observed for the non-ENSO case as compared to those for the strong ENSO case. Therefore, the strong anomalous southwesterly flows favorable for producing extremely heavy rain were associated with the positive geopotential height anomalies over the Philippine Sea coupled with a weaker midlatitude frontal trough over the China coastal area for the strong ENSO case. Whereas, for the non-ENSO case, the strong southwesterly flows were mainly related to the southward penetration of a stronger midlatitude frontal trough over the China coastal area.

The climatological mean state at $850 \mathrm{hPa}$ indicated that the northeast monsoonal flows observed at $1000 \mathrm{hPa}$ over the South China Sea, the Philippine Sea, and the western Pacific were replaced by the southwesterly/ southeasterly/easterly flows over the same areas (not shown). Like those at $1000 \mathrm{hPa}$, the differences of longterm mean state between ENSO and non-ENSO years at $850 \mathrm{hPa}$ also exhibited the PEA pattern with anomalous southwesterlies over South China Sea and the western Pacific and an anomalous anticyclone over the Philippine Sea and the western Pacific. Again, a stronger midlatitude frontal trough at $850 \mathrm{hPa}$ (not shown) was essential for producing strong southwesterly flows during the extremely heavy rain events in non-ENSO years, while in strong ENSO years, the strong southwestly flows were associated with a weaker frontal trough coupled with an anomalous anticyclone over the Philippine Sea.

Like that at $850 \mathrm{hPa}$, the climatological mean state 
TABLE 1. The top six extreme daily rainfall events that occurred in western Taiwan observed in strong ENSO and non-ENSO years during spring (Feb-Mar) of 1978-2000. Normalized anomaly is the daily rainfall anomaly divided by the spring standard deviation. Note that the daily rainfall on the event day was taken from the 1-2-1 running mean.

\begin{tabular}{|c|c|c|c|c|c|c|c|}
\hline \multirow[b]{2}{*}{$\begin{array}{l}\text { Warm } \\
\text { episode }\end{array}$} & \multirow[b]{2}{*}{$\begin{array}{l}\text { Date } \\
\text { Precipitation (mm) } \\
\text { Normalized anomaly }\end{array}$} & \multicolumn{6}{|c|}{ Events } \\
\hline & & $\begin{array}{c}\text { 10 Mar } 1998 \\
47.1 \\
5.65\end{array}$ & $\begin{array}{c}20 \text { Feb } 1998 \\
46.2 \\
5.53\end{array}$ & $\begin{array}{c}\text { 12 Mar } 1983 \\
42.1 \\
4.98\end{array}$ & $\begin{array}{c}25 \operatorname{Mar} 1983 \\
41.8 \\
4.94\end{array}$ & $\begin{array}{c}25 \operatorname{Mar} 1987 \\
39.4 \\
4.62\end{array}$ & $\begin{array}{c}11 \text { Feb } 1983 \\
35.3 \\
4.07\end{array}$ \\
\hline $\begin{array}{c}\text { Non-warm } \\
\text { episode }\end{array}$ & $\begin{array}{l}\text { Date } \\
\text { Precipitation (mm) } \\
\text { Normalized anomaly }\end{array}$ & $\begin{array}{c}9 \text { Feb } 1985 \\
54.5 \\
6.64\end{array}$ & $\begin{array}{c}22 \operatorname{Mar} 1997 \\
49.0 \\
5.91\end{array}$ & $\begin{array}{c}\text { 19 } \operatorname{Mar} 1981 \\
41.0 \\
4.83\end{array}$ & $\begin{array}{c}21 \text { Mar } 1978 \\
40.2 \\
4.73\end{array}$ & $\begin{array}{c}21 \text { Feb } 2000 \\
35.1 \\
4.04\end{array}$ & $\begin{array}{c}16 \text { Mar } 1993 \\
31.6 \\
3.58\end{array}$ \\
\hline
\end{tabular}

at $500 \mathrm{hPa}$ indicated that the west-southwesterly flows prevailed over the South China Sea, the Philippine Sea, and the western Pacific as well (not shown). The difference of the long-term mean state between ENSO and non-ENSO case at $500 \mathrm{hPa}$ again exhibited a PEA pattern with anomalous southwesterlies over the northern South China Sea, Taiwan and adjacent areas.

Figure 10 presents geopotential height and wind fields at $200 \mathrm{hPa}$. The western Pacific trough in the climatological mean state was located along the coastal area of northeast Asia (Fig. 10a). A westerly jet was located over southern Japan. Unlike that in the lower troposphere, the difference in long-term mean state for ENSO and non-ENSO years showed a region of strong anomalous cyclone associated with negative anomaly in geopotential height over east Asia and its coastal area (Fig. 10b). Thus, the anomalous westerly flows prevailed to the south of this negative anomalous center over the South China Sea, the Philippine Sea, Taiwan, and its vicinity. During the heavy rain events in strong ENSO years, a southwesterly jet existed to the east of the trough over the area from eastern China to Japan. Taiwan was located on the anticyclonic side of the entrance region of this jet (Fig. 10c). This is the area where upward motion would be expected from the upper-level jet forcing (Uccellini and Johnson 1979). In non-ENSO years, the westerly jet was located over the same area as that of the climatological mean state although with a weaker intensity (Fig. 10d). Taiwan was again located on the anticyclonic side of the entrance region so that upward motion would be expected, although with a weaker intensity than that in strong ENSO years. The western Pacific trough was stronger during the heavy rain events in strong ENSO years as compared to that in non-ENSO years as indicated by the intensity of negative anomalies in geopotential heighs (Figs. 10e and 10f). The longterm mean condition over the China coastal area also contributed to the stronger western Pacific trough at 200 $\mathrm{hPa}$ during the heavy rain events in strong ENSO years.

From the previous discussion on synoptic situations, it is clear that a midlatitude transient baroclinic system is an important factor for the extremely heavy rain events in both strong ENSO and non-ENSO years. The question arises of how this transient system affects Tai-

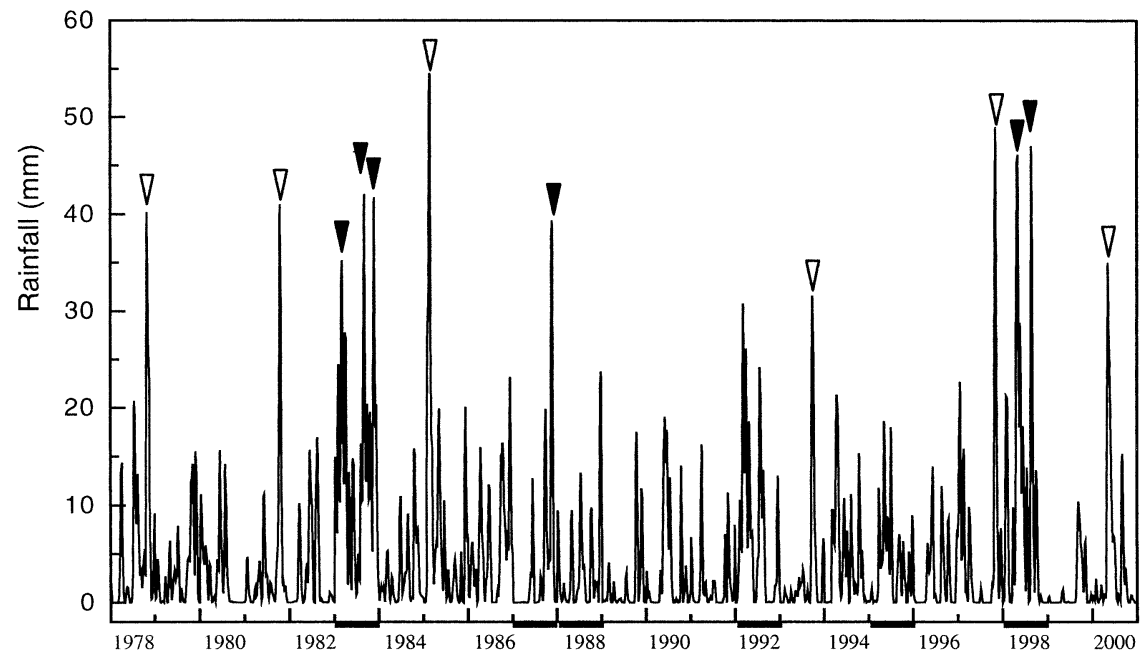

FIG. 7. Time series of the daily rainfall obtained by 1-2-1 running mean in spring season (FebMar) of 1978-2000 over eight stations in western Taiwan. ENSO years are marked by heavy solid line in $x$ axis. The six extremely heavy rain events that occurred in strong ENSO years are indicated by $\boldsymbol{\nabla}$, and in non-ENSO years by $\nabla$. 
(a) $1000 \mathrm{hPa}$ climatological mean state

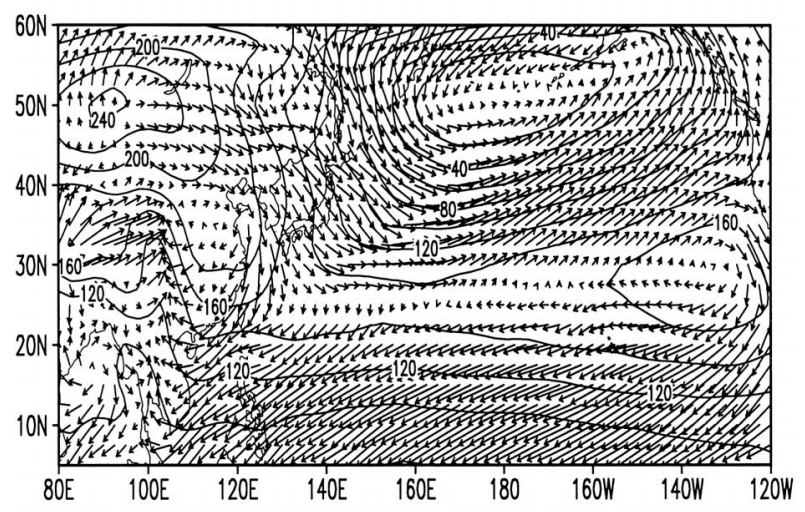

(b) $1000 \mathrm{hPa}$ long-term mean (ENSO - non-ENSO )

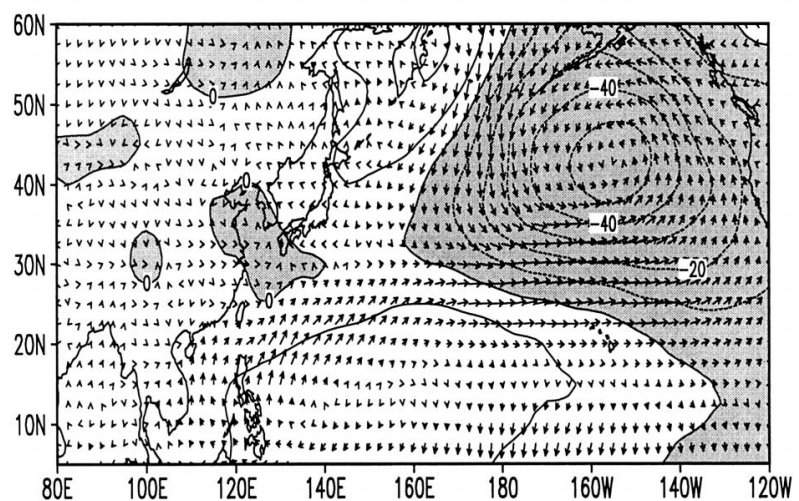

FIG. 8. 1000-hPa geopotential heights (gpm) and wind vectors (m $\mathrm{s}^{-1}$ ) for (a) climatological mean state, (b) difference of seasonal mean between ENSO and non-ENSO years. Areas with negative anomalies of geopotential heights are shaded. Heavy dashed lines indicate frontal trough lines.

wan during the extreme heavy rain events in both strong ENSO and non-ENSO years. To illustrate the characteristics of the transient system, vertical time cross sections at northern Taiwan $\left(25^{\circ} \mathrm{N}, 120^{\circ} \mathrm{E}\right)$ and southern Taiwan $\left(22.5^{\circ} \mathrm{N}, 120^{\circ} \mathrm{E}\right)$ are presented in Fig. 11 . As indicated by the cyclonic wind shear and baroclinicity, the weak northeasterly wind strengthened at the surface and southwesterly wind veered at $850 \mathrm{hPa}$ during the passage of the frontal trough. The frontal trough with relatively weak baroclinicity and cyclonic shear in the lower troposphere passed northern Taiwan $\left(25^{\circ} \mathrm{N}\right.$, $\left.120^{\circ} \mathrm{E}\right)$ and southern Taiwan $\left(22.5^{\circ} \mathrm{N}, 120^{\circ} \mathrm{E}\right)$ on the same day as of the heavy rain event day in strong ENSO years. Whereas, for the non-ENSO years, the frontal trough with relatively strong baroclinicity and cyclonic shear in the lower troposphere passed northern Taiwan on the heavy rain event day and passed southern Taiwan right after the event day. In other words, the frontal trough associated with heavy rain event usually moved (a) $1000 \mathrm{hPa}$ anomaly (strong ENSO)

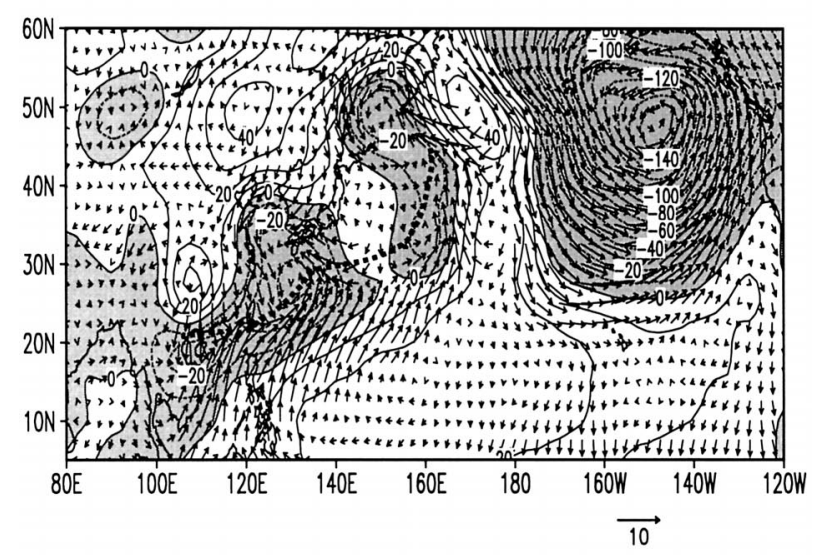

(b) $1000 \mathrm{hPa}$ anomaly ( non-ENSO)

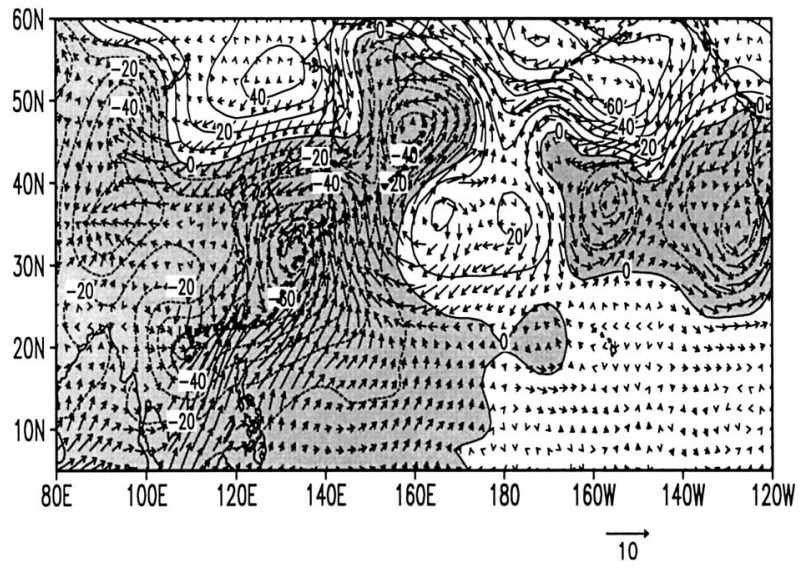

FIG. 9. 1000-hPa geopotential heights (gpm) and wind vectors (m $\mathrm{s}^{-1}$ ) anomalies for the six extremely heavy rain events on the event day in (a) strong ENSO and (b) non-ENSO years. Areas with negative anomalies of geopotential heights are shaded. Heavy dashed lines indicate frontal trough lines.

faster in strong ENSO years than that in non-ENSO years.

\section{b. Moisture flux and vertical motion}

As discussed previously, anomalous southwesterly flow over the northern South China Sea and Taiwan to the southeast of the frontal trough was important for the extremely heavy rain by providing moisture from the tropical area in both cases. It is interesting to know the distribution of moisture transport and flux convergence in the lower troposphere during the extremely heavy rain event. The strong southwesterly moisture transport occurred to the southeast of the $850-\mathrm{hPa}$ frontal trough particularly over Taiwan and the northern South China Sea for cases both in strong ENSO and non-ENSO years (Fig. 12) as would be expected. This strong southwesterly moisture transport converged to the southeast of the frontal trough to form a band of maximum flux convergence. The maximum band extended from south- 
(a) $200 \mathrm{hPa}$ climatological mean state

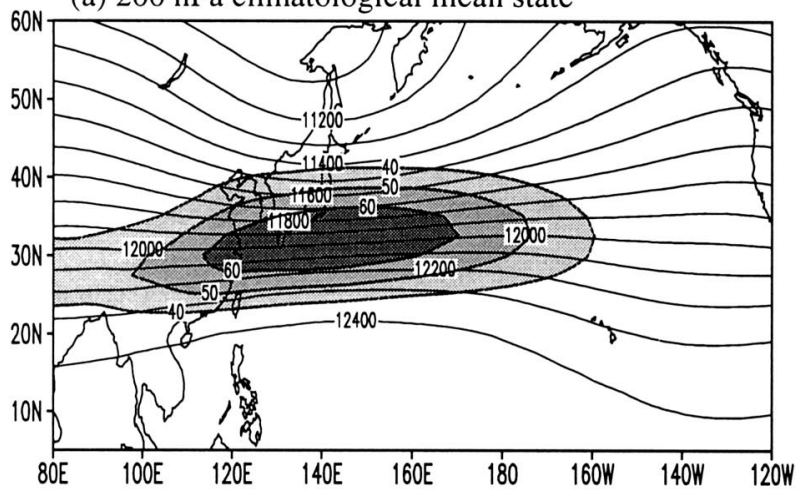

(c) $200 \mathrm{hPa}$ composite ( strong ENSO)

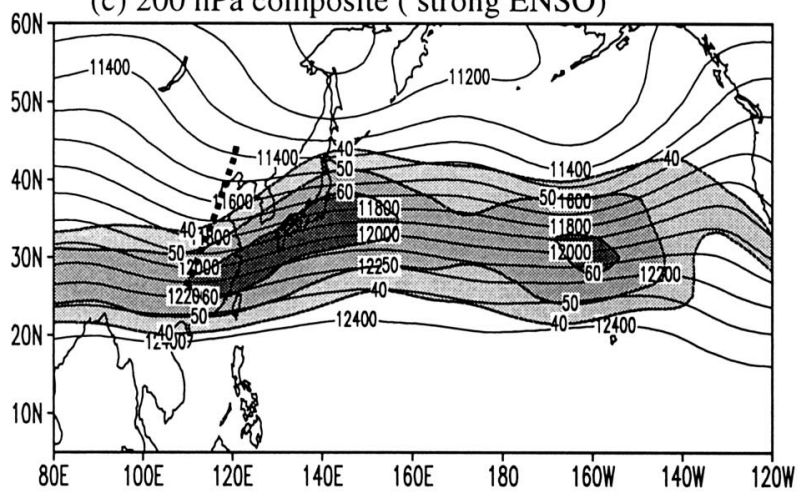

(e) $200 \mathrm{hPa}$ anomaly ( strong ENSO)

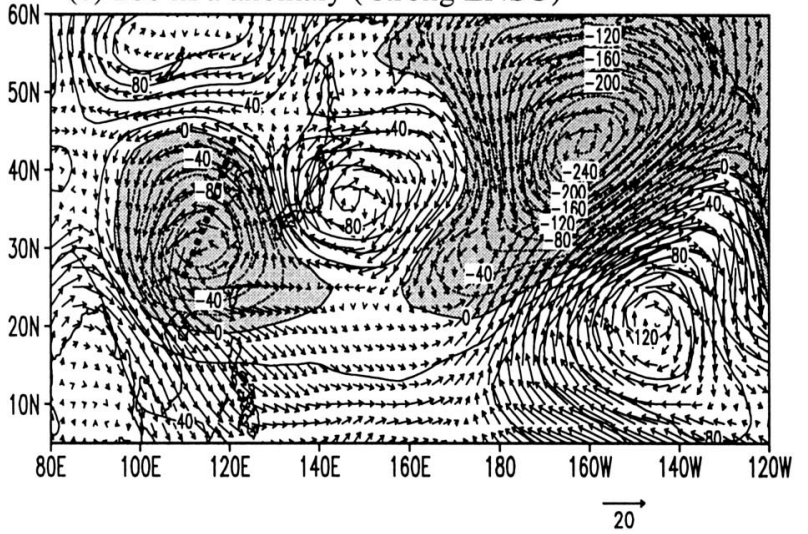

(b) $200 \mathrm{hPa}$ long-term mean (ENSO - non- ENSO)

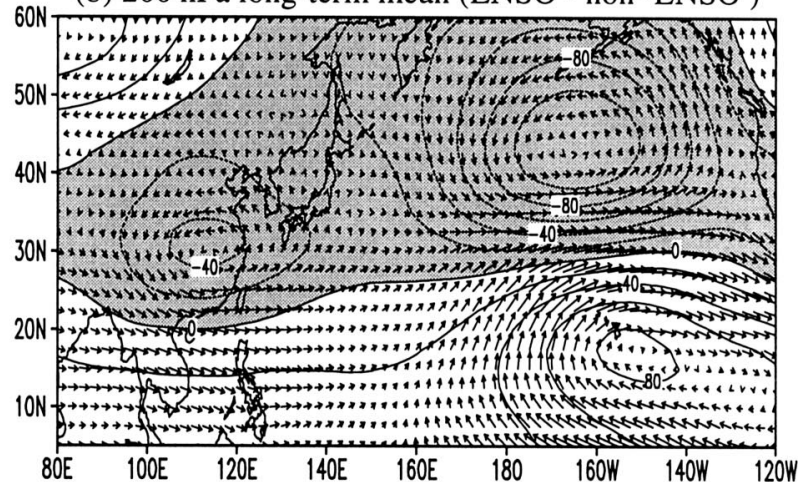

(d) 200 hPa composite ( non- ENSO)

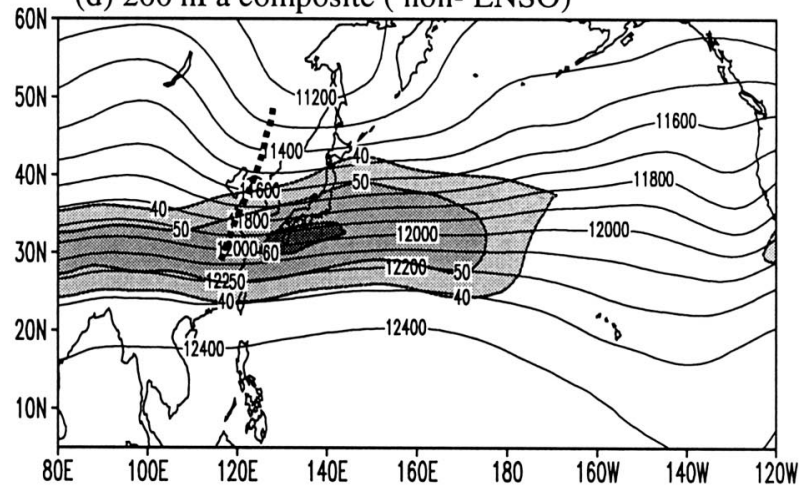

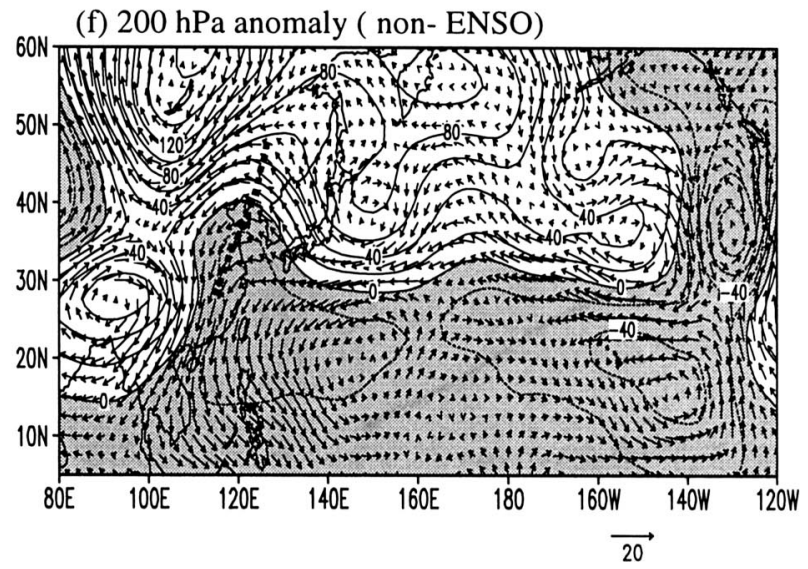

FIG. 10. 200-hPa geopotential heights (gpm) and wind vectors $\left(\mathrm{m} \mathrm{s}^{-1}\right)$ of (a) climatological mean state, (b) difference of long-term mean for the ENSO and non-ENSO years. (c), (d) Composites and (e), (f) anomalies for the six extremely heavy rain events on the event day in strong ENSO and non-ENSO years. Isotaches in (a), (c), (d) with 40,50, and $60 \mathrm{~m} \mathrm{~s}^{-1}$ are shaded. Areas with negative anomalies of geopotential heights in (b), (e), (f) are shaded. Heavy dashed lines indicate trough lines.

ern China and the northern South China Sea east-northeastward, passing through Taiwan area to the western North Pacific. Therefore, the existence of the lowertropropheric frontal system and the accompanied moisture flux convergence appeared to be instrumental for producing the extremely heavy rain event.

Figure 13 presents the vertical motion at $700 \mathrm{hPa}$ during the extremely heavy rain event. It is clear that a band of strong upward motion was located along and to the south of the $850-\mathrm{hPa}$ frontal trough extending from southern China east-northeastward, passing through Taiwan to Japan. The area of maximum upward motion was approximately collocated with the area of maximum moisture flux convergence as presented in Fig. 12. Therefore, the existence of the lower-tropospheric frontal system is instrumental in the heavy rain event by providing maximum moisture flux convergence and maximum upward motion. The temporal variations 

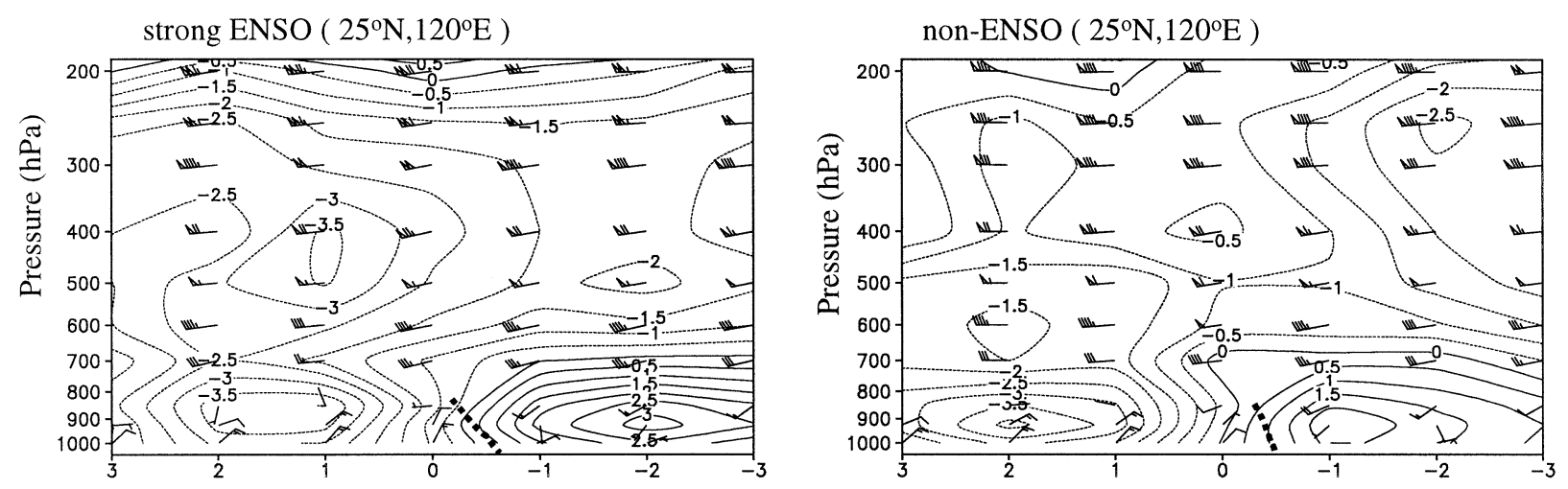

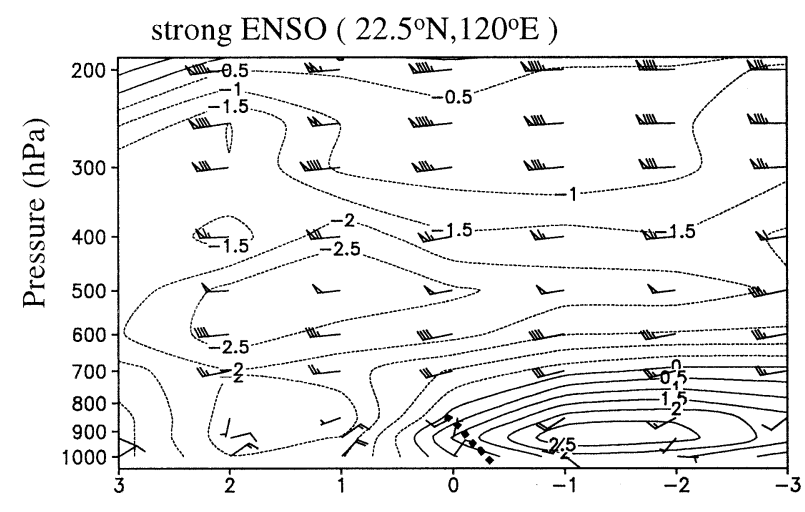

(a)

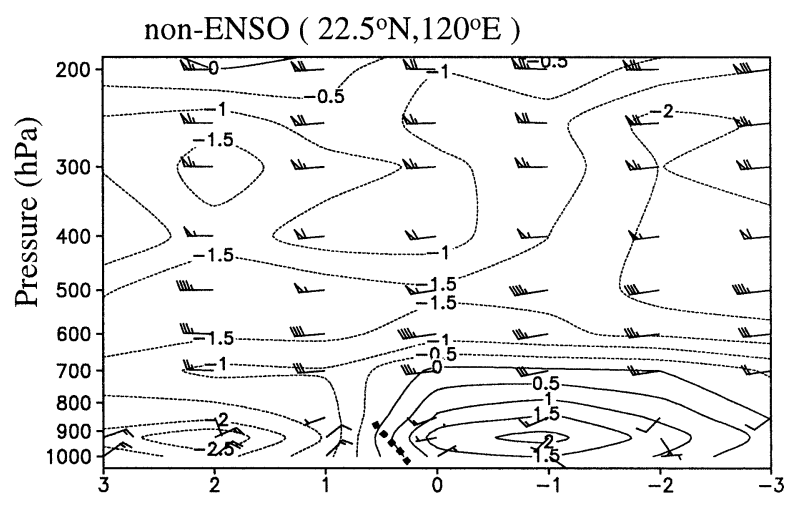

(b)

FIG. 11. Vertical time cross section from 3 days before $(-3)$ to 3 days after $(+3)$ the event day $(0)$ for temperature anomalies $\left({ }^{\circ} \mathrm{C}\right)$ and winds at $25^{\circ} \mathrm{N}, 120^{\circ} \mathrm{E}$ (northern Taiwan) and $22.5^{\circ} \mathrm{N}, 120^{\circ} \mathrm{E}$ (southern Taiwan) for the six extremely heavy rain events in (a) strong ENSO and (b) non-ENSO years. Pennants represents $25 \mathrm{~m} \mathrm{~s}^{-1}$, full wind barb $5 \mathrm{~m} \mathrm{~s}^{-1}$, and half-wind barb $2.5 \mathrm{~m} \mathrm{~s}^{-1}$. Heavy dashed lines indicate the frontal trough position.

of vertical motion at northern Taiwan $\left(25^{\circ} \mathrm{N}, 120^{\circ} \mathrm{E}\right)$ and southern Taiwan $\left(22.5^{\circ} \mathrm{N}, 120^{\circ} \mathrm{E}\right)$ in the ENSO and nonENSO years are presented in Figs. 14a and 14b, respectively. In strong ENSO years, upward motion increased from 2 days before the event day to reach a maximum value of $>-16 \times 10^{-2} \mathrm{~Pa} \mathrm{~s}^{-1}$ at $500 \mathrm{hPa}$ over northern Taiwan and $>-14 \times 10^{-2} \mathrm{~Pa} \mathrm{~s}^{-1}$ at 700 $\mathrm{hPa}$ over southern Taiwan right over the lower-tropospheric front on the event day. Downward motion existed after the event day in the lower troposphere over northern and southern Taiwan, indicating the existence of the across-front thermally direct secondary circulation. In non-ENSO years, upward motion increased from 3 days before to reach a maximum value of $>-14 \times$ $10^{-2} \mathrm{~Pa} \mathrm{~s}^{-1}$ at $500 \mathrm{hPa}$ over northern Taiwan on 1 day before and $>-8 \times 10^{-2} \mathrm{~Pa} \mathrm{~s}^{-1}$ at 700-500 hPa over southern Taiwan on the event day ahead of the lowertropospheric frontal trough. Note that the maximum upward motion during the extremely heavy rain event was much greater in strong ENSO years over either northern or southern Taiwan. This was consistent with a stronger upper-level jet at $200 \mathrm{hPa}$ (Fig. 10c) in strong ENSO years as compared to that in non-ENSO years, although the midlatitude frontal trough in the lower troposphere was stronger in non-ENSO years.

\section{Discussion}

The large-scale conditions discussed in the previous section demonstrate that the anomalously strong southwesterly flows in the lower troposphere over Taiwan and the northern South China Sea were essential for producing heavy spring rain events by providing moisture from the tropical area. However, these conditions were associated with quite different large-scale circulation systems in strong ENSO and non-ENSO years. In strong ENSO years, the strong southwesterly flows were associated with a weaker frontal midlatitude trough in the lower troposphere coupled with an anomalous anticyclone over the Philippine Sea. Whereas, in nonENSO years, a stronger midlatitude frontal trough was needed for producing strong southwesterly flows because negative geopotential height field existed over the Philippine Sea and the western Pacific. Below we examine the question of whether these differences are also 
(a) strong ENSO

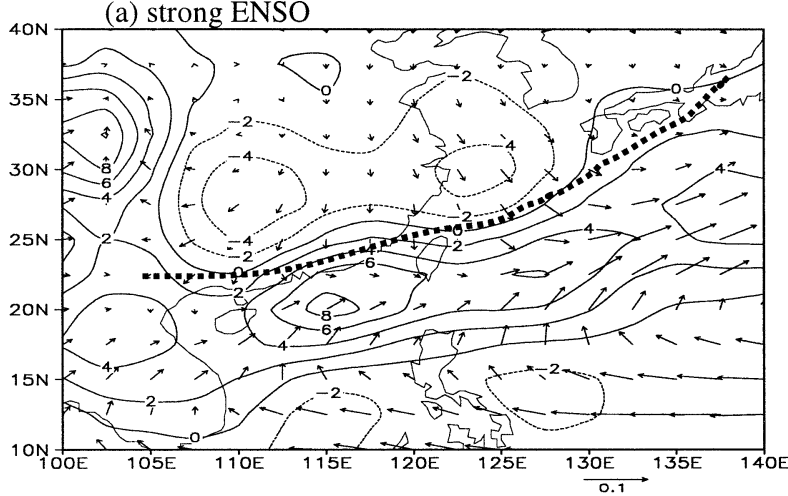

(b)non-ENSO

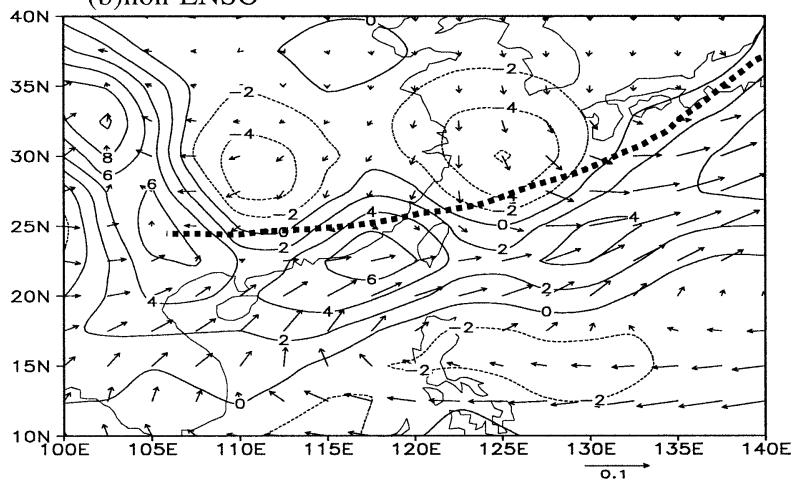

FIG. 12. Moisture transport $\left(q \overline{\mathbf{V}}\right.$ arrows; $\left.\mathrm{g} \mathrm{kg}^{-1} \mathrm{~m} \mathrm{~s}^{-1}\right)$ and moisture flux convergence $\left(-\boldsymbol{\nabla} \cdot q \overline{\mathbf{V}} ; 10^{-5} \mathrm{~g} \mathrm{~kg}^{-1} \mathrm{~s}^{-1}\right)$ in the $1000-850-\mathrm{hPa}$ layer for the extremely heavy rain events on the event day in (a) strong ENSO and (b) non-ENSO years. Flux convergence analyzed at $2 \times 10^{-5} \mathrm{~g} \mathrm{~kg}^{-1} \mathrm{~s}^{-1}$ intervals with convergence indicated by solid lines and divergence by dashed lines. Heavy dashed line indicates 850 -hPa frontal trough.

responsible for more frequent heavy rain events and more rainfall amount in ENSO years.

To examine the effect of these differences on the overall daily rainfall characteristic, scatter diagrams of 850$\mathrm{hPa}$ geopotential height anomalies over the area to the north of Taiwan $\left(25^{\circ}-27.5^{\circ} \mathrm{N}, 120^{\circ}-122.5^{\circ} \mathrm{E}\right)$ and the corresponding daily rainfall in February-March of ENSO and non-ENSO years are presented in Fig. 15. Negative correlations exist between 850 -hPa geopotential height anomalies over the area to the north of Taiwan and the daily rainfall with $99 \%$ significance level for the top 50 daily rainfall events in both ENSO and nonENSO years (Fig. 15a). However, the correlation coefficient in non-ENSO years was much higher than that in ENSO years. This relationship was also true between all the cases with negative $850-\mathrm{hPa}$ geopotential height anomalies and the corresponding daily rainfalls as presented in Fig. 15b. Again, the correlation coefficient was much higher in non-ENSO years than in ENSO years. These statistical relations tend to suggest that only a relatively weaker midlatitude trough in the lower troposphere over the vicinity of Taiwan was needed to produce the overall spring rainfall in ENSO years. This

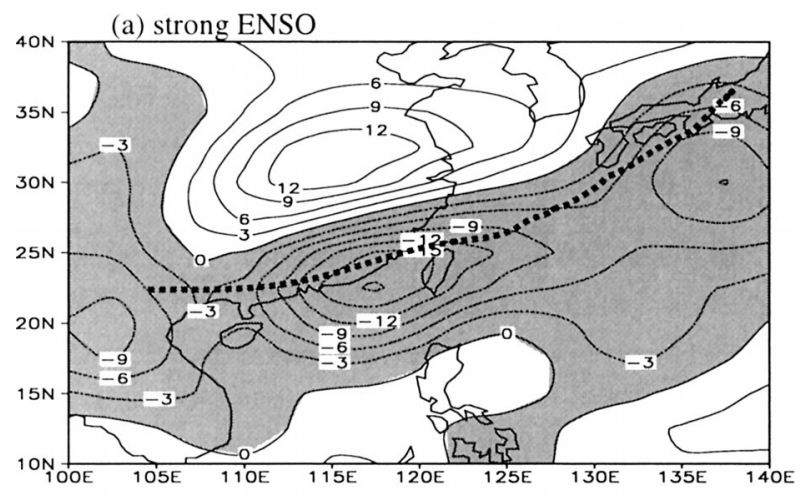

(b)non-ENSO

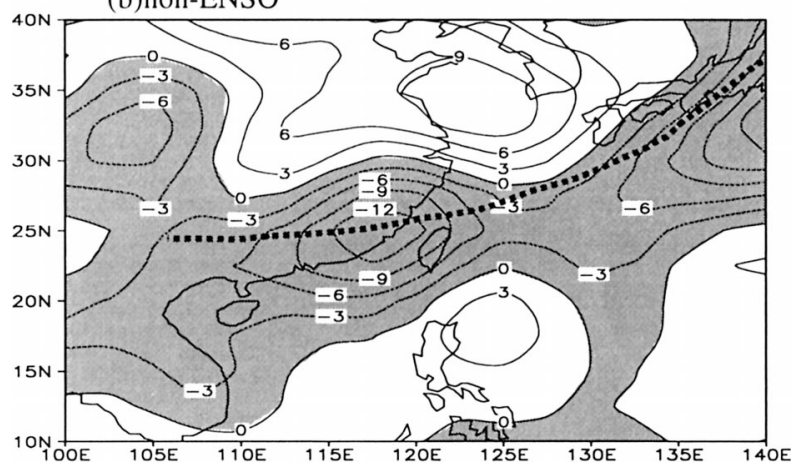

FIG. 13. Vertical $p$ velocity $\left(10^{-2} \mathrm{~Pa} \mathrm{~s}^{-1}\right)$ at $700 \mathrm{hPa}$ for the six extremely heavy rain events in (a) strong ENSO and (b) non-ENSO years. Negative values (upward motions) are shaded. Heavy dashed line indicates $850-\mathrm{hPa}$ frontal trough.

is consistent with the result obtained in the previous section for the extremely heavy rain events.

To further explore the role of the PSAC in producing strong southwesterly flows in the lower troposphere over Taiwan and the northern South China Sea, the correlation between $850-\mathrm{hPa}$ geopotential height anomalies over the Philippine Sea $\left(10^{\circ}-20^{\circ} \mathrm{N}, 130^{\circ}-140^{\circ} \mathrm{E}\right)$ and wind velocities over the southern Taiwan Strait $\left(20^{\circ}-\right.$ $22.5^{\circ} \mathrm{N}, 117.5^{\circ}-120^{\circ} \mathrm{E}$ ) was examined. The region of the Philippine Sea corresponds to that used by Tian and Yasunari (1998). A scattergram of these two variables for the top 50 daily rainfall events is presented in Fig. $16 \mathrm{a}$ and one for all the cases with negative $850-\mathrm{hPa}$ geopotential height anomalies is presented in Fig. 16b in ENSO and non-ENSO years. The positive correlation with $95 \%$ significance level existed either for the top 50 daily rainfall events or for all the cases with negative 850-hPa geopotential height anomalies events in ENSO years, while in non-ENSO years, these correlation coefficients were close to zero. Statistically, again the PSAC in the lower troposphere in ENSO years plays an important role in producing strong southwesterly flows over Taiwan and the northern South China Sea.

In view of the different large-scale conditions associated with spring heavy rainfall events in ENSO and non-ENSO years, an interesting question arises regard- 

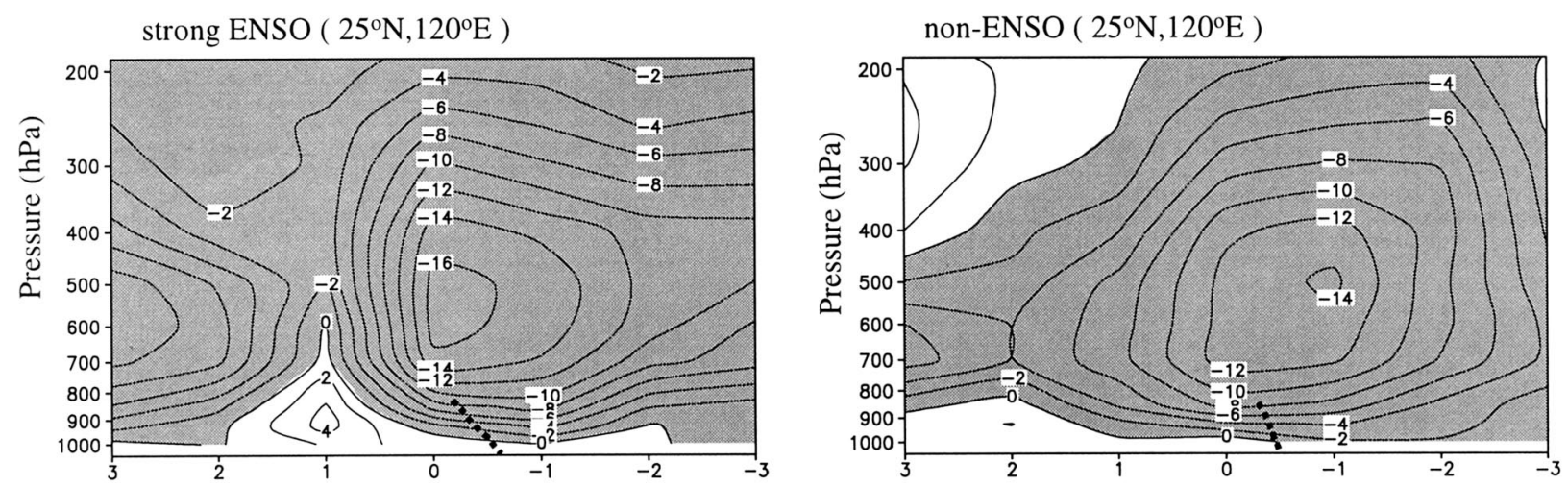

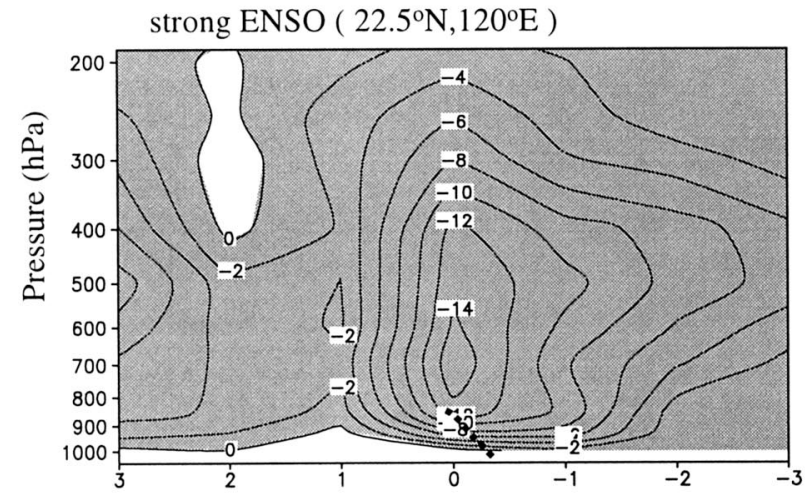

(a)

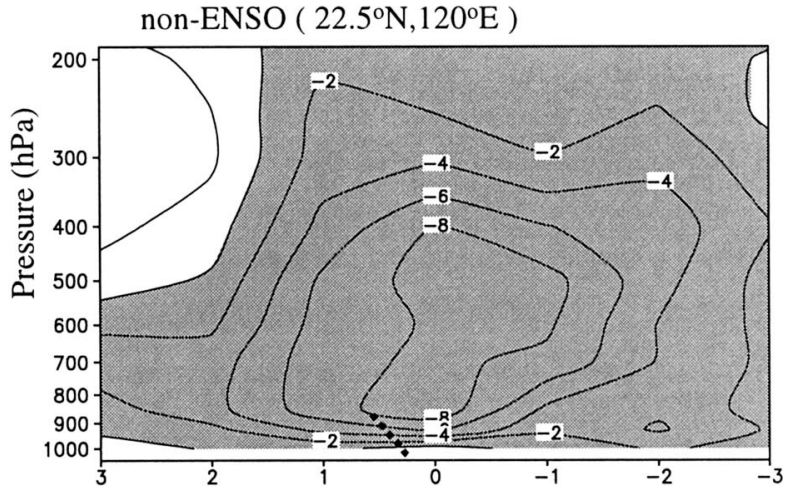

(b)

FIG. 14. As in Fig. 11 except for vertical p velocity $\left(10^{-2} \mathrm{~Pa} \mathrm{~s}^{-1}\right)$. Negative values (upward motions) are shaded.
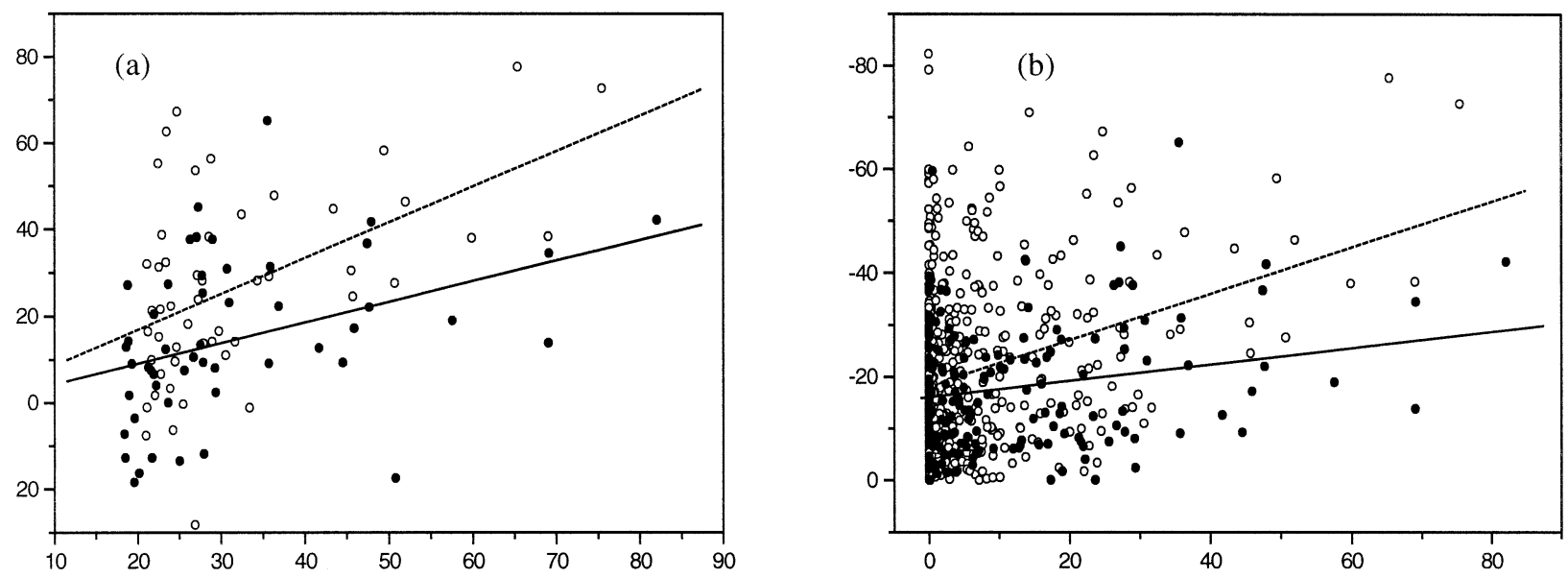

FIG. 15. Scattergram of (a) 850 -hPa geopotential height anomalies over the area to the north of Taiwan $\left(25^{\circ}-27.5^{\circ} \mathrm{N}, 120^{\circ}-122.5^{\circ} \mathrm{E}\right)$ and the daily rainfall for the top 50 daily rainfall events and (b) all the cases with negative 850-hPa geopotential height anomalies over the same area and the corresponding daily rainfalls during ENSO (solid circle) and non-ENSO years (open circle). The fitting linear regression equations in (a) are $y=0.395-0.474 x$ with a correlation coefficient of -0.371 for ENSO years (solid line) and $y=-0.353-0.825 x$ with a correlation coefficient of -0.497 for non-ENSO (dashed line) years. The fitting linear regression equations in (b) are $y=-16.063-0.158 x$ with a correlation coefficient of -0.197 for ENSO years (solid line) and $y=-18.217-0.444 x$ with a correlation coefficient of -0.287 for non-ENSO (dashed line) years. Abscissa is daily rainfall $(\mathrm{mm})$ and ordinate is the corresponding 850 -hPa geopotential height anomaly (gpm). 

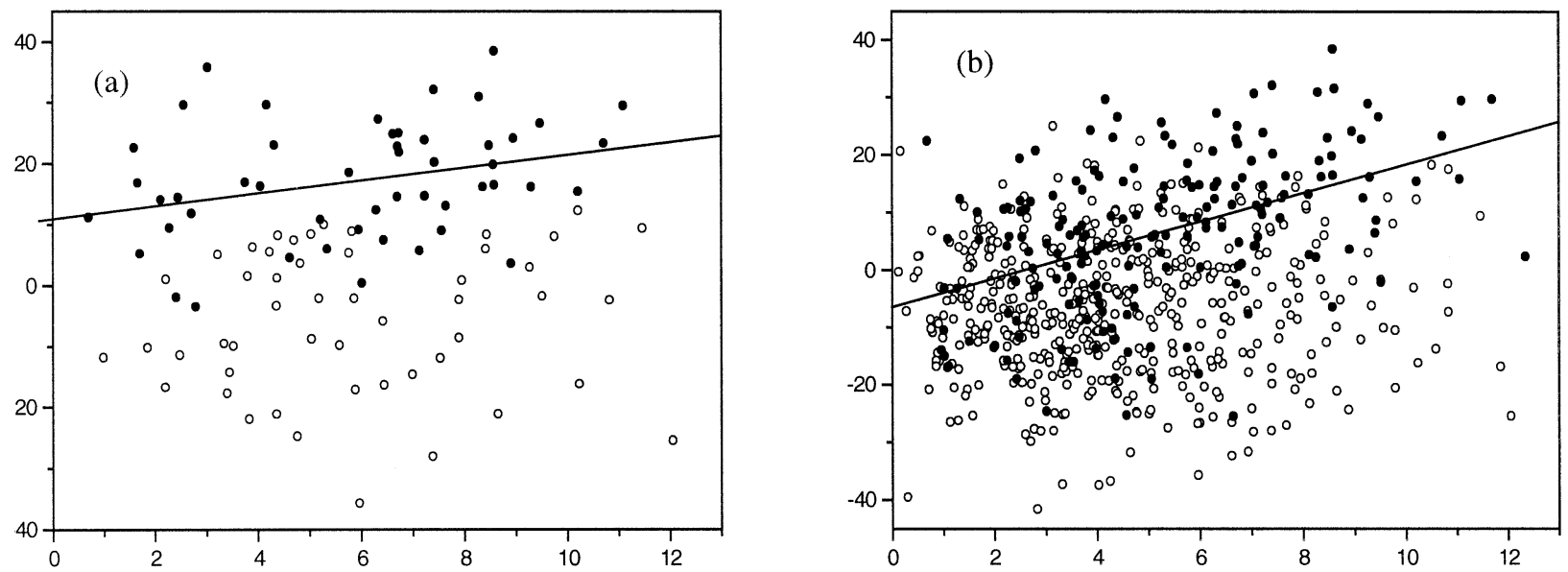

FIG. 16. Scattergram of $850-\mathrm{hPa}$ geopotential height anomalies over the Philippine Sea $\left(10^{\circ}-20^{\circ} \mathrm{N}, 130^{\circ}-140^{\circ} \mathrm{E}\right)$ and wind velocities over the southern Taiwan Strait $\left(20^{\circ}-22.5^{\circ} \mathrm{N}, 117.5^{\circ}-120^{\circ} \mathrm{E}\right)$ for (a) the top 50 daily rainfall events and (b) all the cases with negative 850 -hPa geopotential height anomalies over the area to the north of Taiwan $\left(25^{\circ}-27.5^{\circ} \mathrm{N}, 120^{\circ}-122.5^{\circ} \mathrm{E}\right)$ during ENSO (solid circle) and non-ENSO years (open circle). The fitting linear regression equations in (a) is $y=10.956+1.045 x$ with a correlation coefficient of 0.293 and in (b) is $y=-6.447+2.478 x$ with a correlation coefficient of 0.461 for ENSO years. Ordinate is 850 -hPa geopotential height anomaly (gpm) and abscissa is the corresponding wind velocity $\left(\mathrm{m} \mathrm{s}^{-1}\right)$.

ing the occurrence frequency of the frontal trough systems with different intensities in both cases. Figure 17 presents the mean annual frequency of the daily 850$\mathrm{hPa}$ geopotential height anomalies over the area to the north of Taiwan $\left(25^{\circ}-27.5^{\circ} \mathrm{N}, 120^{\circ}-122.5^{\circ} \mathrm{E}\right)$ for ENSO and non-ENSO years during February-March of 19782000. Note that the frequency with the high negative geopotential height anomalies was much higher in nonENSO years as compared to that in ENSO years. This is in good agreement with the result obtained in the previous sections that a stronger midlatitude frontal trough in the lower troposphere existed during the extremely heavy rain event in non-ENSO years. The frequencies with small to medium values of negative geopotential height anomalies were higher in ENSO years. This is consistent with the fact that more extremely heavy rain events (Fig. 6) and more rainfall (Chen et

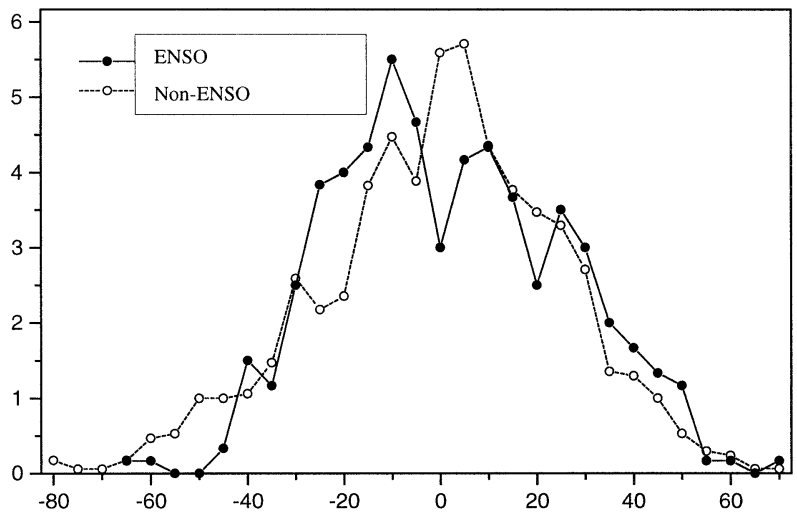

FIG. 17. The mean annual frequency of the daily $850-\mathrm{hPa}$ geopotential height anomalies ( $x$ axis; at 5 gpm intervals) over the area to the north of Taiwan $\left(25^{\circ}-27.5^{\circ} \mathrm{N}, 120^{\circ}-122.5^{\circ} \mathrm{E}\right)$ during the ENSO (solid line) and non-ENSO years (dashed line) in 1978-2000. al. 2003) were observed in ENSO years. In other words, synoptic events tend to be weaker in ENSO years, but that this was offset by the fact that weaker events can conspire with the seasonal anomaly to still make heavy rain events.

\section{Summary}

Before the mei-yu rainy season of mid-May to midJune Taiwan experiences a relatively dry spring particularly over central and southwestern Taiwan. The spring rainfall, however, exhibits a large interannual variation such that the occurrence of drought and heavy rain events is not uncommon. Therefore, a better understanding of this variation becomes one of the most important meteorological issues that is crucial for the management of water resources. In this study, rainfall data at 15 stations in Taiwan and grid data of meteorological parameters at different mandatory levels from the National Centers for Environmental Prediction-National Center for Atmospheric Research were used to reveal the characteristics of large-scale circulations associated with spring heavy rain events over Taiwan in the warm and nonwarm episodes. The effects of interdecadal variation on the relationship of spring rainfall and ENSO were also examined.

From the wavelet transform and the correlation analyses for spring rainfall and Niño-3 SST, it is clear that the different regime of interdecadal variation of Pacific ocean that occurred in the late 1970s exerts significant effect on the relationship between ENSO and spring rainfall in Taiwan. The pronounced positive correlation between cold season Niño-3 SST and the following spring rainfall over western Taiwan has only existed since the late 1970s. To investigate why extremely 
heavy rain events occur more frequently in strong ENSO years as compared to those in non-ENSO years, six top daily rainfall events that occurred in strong ENSO and non-ENSO years were selected. Composite and anomaly fields reveal that large-scale features were quite different during the extremely heavy rain events in strong ENSO and non-ENSO years. The anomalous southwesterly flows in the lower troposphere over Taiwan and the northern South China Sea were essential for producing extremely heavy rain event by providing moisture from the tropical area. In strong ENSO years, these strong southwesterly flows were associated with an anomalous anticyclone over the Philippine Sea (PSAC) and the weaker negative geopotential height anomalies over the eastern China coastal area in the lower troposphere, while in non-ENSO years, more intense negative geopotential height anomalies over the China coastal area were essential for producing strong southwesterly flows in the lower troposphere. The midlatitude transient baroclinic system with different intensity was important in this aspect as the lower-tropospheric frontal trough moved into the area to produce the negative geopotential height anomalies with different strength. Composite fields also showed that the band of maximum moisture flux convergence tended to collocate with the band of maximum upward motion along and to the south of the 850-hPa frontal trough. The moisture flux convergence and upward motion were the key factors for generating heavy rain. In addition, much stronger upper-level jet at $200 \mathrm{hPa}$ in strong ENSO years provided much greater upward motion as compared to that in non-ENSO years. Therefore, it is clear that the intrusion of a weaker midlatitude frontal system into the eastern China coastal area coupled with the PSAC in the lower troposphere was primarily responsible for the spring heavy rain event in strong ENSO years, while in non-ENSO years, an intrusion of a much stronger midlatitude frontal system into the China coastal area was necessary to generate spring heavy rain event. This difference is also instrumental for the more frequent heavy rainfall events and greater rainfall amount observed in ENSO years.

Acknowledgments. This research was supported by Grants NSC91-2119-M-002-029, NSC91-2621-Z-002004, and NSC91-2111-M-002-007.

\section{REFERENCES}

Chang, C. P., Y. S. Zhang, and T. Li, 2000a: Interannual and interdecadal variations of the East Asian summer monsoon and tropical Pacific SSTs. Part I: Roles of the subtropical ridge. J. Climate, 13, 4310-4325.

,$- \ldots$, and $\longrightarrow, 2000 \mathrm{~b}$ : Interannual and interdecadal variations of the East Asian summer monsoon and tropical Pacific SSTs. Part II: Meridional structure of the monsoon. J. Climate, 13, 4326-4340.

Chen, G. T. J., Z. H. Jiang, and M. C. Wu, 2003: Spring heavy rain events in Taiwan during warm episodes and the associated largescale conditions. Mon. Wea. Rev., 131, 1173-1188.

Halpert, M. S., and C. F. Ropelewski, 1992: Surface temperature patterns associated with the southern oscillation. J. Climate, $\mathbf{5}$, $577-593$.

Kalnay, E., and Coauthors, 1996: The NCEP/NCAR 40-Year Reanalysis Project. Bull. Amer. Meteor. Soc., 77, 437-471.

Kang, I., and Y. Jeong, 1996: Association of interannual variations of temperature and precipitation in Seoul with principal modes of Pacific SST. J. Korean Meteor. Soc., 32, 339-345.

Kumar, P., and E. Foufoula-Georgiou, 1993: A new look at rainfall fluctuations and scaling properties of spatial rainfall using orthogonal wavelets. J. Appl. Meteor., 32, 209-222.

Lau, K. M., and H. Y. Weng, 1995: Climate signal detection using wavelet transform: How to make a time series sing. Bull. Amer. Meteor. Soc., 76, 2391-2402.

Liu, P. C., and G. S. Miller, 1996: Wavelet transforms and ocean current data analysis. J. Atmos. Oceanic Technol., 13, 10901099.

Morlet, J., 1983: Sampling theory and wave propagation. Issues in Acoustic Signal/Image Processing and Recognition, C. H. Chen, Ed., NATO ASI Series, Vol. 1, Springer-Verlag, 233-261.

Nakamura, H., G. Lin, and T. Yamagata, 1997: Decadal climate variability in the North Pacific during the recent decades. Bull. Amer. Meteor. Soc., 78, 2215-2225.

Nitta, T., and S. Yamada, 1989: Recent warming of tropical sea surface temperature and its relationship to the Northern Hemisphere circulation. J. Meteor. Soc. Japan, 67, 375-383.

Ropelewski, C. F., and M. S. Halpert, 1987: Global and regional scale precipitation patterns associated with the El Niño/Southern Oscillation. Mon. Wea. Rev., 115, 1606-1626.

Tao, S. Y., and Q. Zhang, 1998: Response of the East Asian summer monsoon to ENSO events (in Chinese). Sci. Atmos. Sin., 22, 399-407.

Tian, S. F., and T. Yasunari, 1998: Climatological aspects and mechanism of spring persistent rain over central China. J. Meteor. Soc. Japan, 76, 57-71.

Tomita, T., and T. Yasunari, 1996: Role of the northeast winter monsoon on the biennial oscillation of the ENSO/monsoon system. J. Meteor. Soc. Japan, 74, 399-413.

Torrence, C., and G. P. Compo, 1998: A practical guide to wavelet analysis. Bull. Amer. Meteor. Soc., 79, 61-78.

Trenberth, K. E., and W. J. Hurrell, 1994: Decadal atmosphere-ocean variations in the Pacific. Climate Dyn., 9, 303-319.

Uccellini, L. W., and D. R. Johnson, 1979: The coupling of upper and lower troposphic jet streaks and implications for the development of severe convective storms. Mon. Wea. Rev., 107, 682703.

Wang, B., 1995: Interdecadal changes in El Niño onset in the last four decades. J. Climate, 8, 267-285.

— , and Y. Wang, 1996: Temporal structure of the Southern Oscillation as revealed by waveform and wavelet analysis. J. Climate, 9, 1586-1598.

- R. G. Wu, and X. H. Fu, 2000: Pacific-East Asian teleconnection: How does ENSO affect East Asian climate? J. Climate, 13, 1517-1536.

Wang, J.-T., and J.-W. Hwu, 1994: Springtime East Asia large scale characteristics post ENSO. Part I: The spatial distribution of SST and OLR (in Chinese). Atmos. Sci., 22, 339-360.

Weng, H. Y., and K. M. Lau, 1994: Wavelets, period doubling, and time-frequency localization with application to organization of convection over the tropical western Pacific. J. Atmos. Sci., 51, $2523-2541$.

_ _ _ , and Y. Xue, 1999: Multi-scale summer rainfall variability over China and its long-term link to global sea surface temperature variability. J. Meteor. Soc. Japan, 77, 845-857.

Yen, M. C., and T. C. Chen, 2000: Seasonal variation of the rainfall over Taiwan. Int. J. Climatol., 20, 803-809.

Zhang, R., A. Sumi, and M. Kimoto, 1996: Impact of El Niño on the East Asian monsoon: A diagnostic study of the '86/87 and '91/ 92 events. J. Meteor. Soc. Japan, 74, 49-62. 